\title{
INAUGURATION CEREMONY IN UKRAINE AS A FACTOR OF CULTURAL DIPLOMACY
}

\author{
Oksana Zakharova \\ Doctor of Historical Sciences, Professor, Independent Researcher \\ e-mail: mikepriluki@gmail.com,orcid.org/0000-0002-2143-7020
}

\section{Summary}

State civil and military ceremonies, different in their content and form (coronation of monarchs, inauguration, military reviews and parades, etc.), are important in the exercising by the state of its political, ideological and cultural functions.

Cultural diplomacy is a component of public diplomacy, which, in turn, is one of the tools for creating the image of the state, its attractiveness for the countries of the world community.

As one of the communication technologies in the process of legitimizing government institutions, the inauguration ceremony is an important mechanism of cultural diplomacy.

Despite the fact that in the states of the post-Soviet space, after the October 1917 coup, the natural process of the development of state ceremonial culture was disrupted, the inauguration ceremony in Ukraine is the program of the current government, politics and the prestige of the state.

The very specificity of the inauguration as a social phenomenon makes the ceremonial action a kind of illustration of the customs and tastes of the ruling elite, which also establishes a balance between the participants in the ceremony and society.

The history of ceremonial culture shows that in most cases the attitude to the ceremony of coming to power is the attitude to the power itself.

Keywords: state image, political elite, communication technologies, public diplomacy, state ceremonials.

DOI: https://doi.org/10.23856/3881

\section{Introduction}

The legitimization of power institutions is directly related to various forms of visual communication technologies, including the inauguration ceremony.

The novelty of the research lies in the study of the inauguration ceremony in Ukraine as a factor of cultural diplomacy, capable of influencing the attitude of the world community towards the country, and as a result, contribute to the formation of the state's image.

The relevance of the work lies both in the insufficient study of the problem of the functioning of the institution of cultural diplomacy in modern Ukraine, and in the fact that knowledge of the features of its functioning will make it possible to judge the openness of society, its moral values, and the attitude of citizens towards the ruling elite.

Purpose of the research. Based on the analysis of published sources, identify the peculiarities of the development of the inauguration ceremony in Ukraine as a factor of cultural diplomacy and, as a consequence, the mechanism of public diplomacy.

\section{Cultural diplomacy as a component of public diplomacy}

The classical concept of "public diplomacy" was presented by E. Gullion (Dean of the Fletcher School of Law and Diplomacy at Tufts University) during the formation of the Center 
for Public Diplomacy. E.R. Murrow in 1965. In a brochure about the Center, this concept was presented as follows: "Public diplomacy ... deals with the influence of public attitudes on the implementation of foreign policy. It includes dimensions of international relations that go beyond traditional diplomacy: the cultivation of public opinion by governments in other countries, the interaction of private interest groups of one country with another, the coverage of international relations and their impact on state policy, interaction between those whose job is to communicate (diplomats and foreign correspondents) and the process of intercultural communication". E. Gullion himself wrote: "By public diplomacy we mean the means by which governments, private groups and individuals change the attitudes and opinions of other peoples and governments in such a way as to influence their foreign policy decisions" (Lukin, 2013: 70).

The concepts of cultural diplomacy and public diplomacy are not identical. The resources of cultural diplomacy are limited by its means, including: student exchanges; branches of educational institutions and libraries; organization of exhibitions of works of art and tours of theater groups; tourism development; sports events with the participation of athletes from foreign countries, etc.

The organization of these projects, their practical implementation requires significant financial costs, as well as the involvement of high-level professionals into the field of intercultural communication.

Another problem in the development of cultural diplomacy lies in its so-called unilateral action.

The organizers of various cultural programs can only guess how much their project will be in demand by various categories of the local population, whose representatives will want to expand their knowledge of the host country in order to start studying its language, history, economy, etc. But this will be the next stage in the development of public diplomacy. Cultural diplomacy is especially important at the initial stage, when it is necessary to arouse as much of the population as possible an interest in a particular state. In this regard, in our opinion, state ceremonies, and first of all, the inauguration ceremony, acquire special significance.

Political symbolism developed in a strict system of borrowings, which in some cases are articulated by the authorities, but for the most part require special explanations, referring to the sources of their origin.

The first inauguration (from the Latin inauguro - dedicating) - the solemn inauguration of US President George Washington took place on April 30, 1789. To the accompaniment of artillery volleys and the ringing of bells G. Washington entered the building where the Congress was in session. Putting his left hand on the Bible, he took the oath.

Another tradition that has survived to this day is the President's speech, which is still considered one of the shortest - 135 words. The first President of the United States can also be considered the ancestor of the inaugural ball, at which he performed the minuet.

Despite the fact that compared to the 18th century the inauguration ceremony has changed little, it has undergone a number of significant changes in accordance with historical needs.

\section{Inauguration of Viktor Yushchenko}

Apparently it was the American version that was taken as the basis for the Ukrainian scenario for the inauguration of Viktor Yushchenko, one of the largest initiation ceremonies in Ukrainian history. But before talking about the ceremony on January 23, 2005, let us note that the first "unofficial" inauguration of V. Yushchenko took place on November 23, 2004 at an extraordinary session of the Parliament to discuss the situation related to the presidential elections in Ukraine. 
There was no quorum to make a decision to express no confidence to the Central Election Commission (CEC). The Chairman of the Verkhovna Rada V. Lytvyn said that "it is practically impossible to cancel the CEC decision on the elections." After the opposition candidate V. Yushchenko made a speech in which he proclaimed his victory in the elections, the Speaker of the Parliament V. Lytvyn interrupted the session of the Verkhovna Rada of Ukraine and warned that he would not allow V. Yushchenko to take the oath in the Parliament hall. However, he came to the podium and swore allegiance to Ukraine on the Ostrog Bible. (According to the law, the President at the inauguration takes the oath on the Constitution. In 1994 the President of Ukraine L. Kuchma took the oath on the current Constitution with amendments and the Peresopnytsia Gospel). This was greeted with shouts of his supporters: "Bravo, sir President!" and a choral performance of the anthem of Ukraine.

According to Y. Timoshenko, the meeting was attended by real representatives of the interests of the Ukrainian people and there were no "traitors of the people of Ukraine...". Subsequently she urged not to enter into any negotiations with the authorities, "just knock them out of the offices," to appoint a government and work further.

Several factors formed the basis of the concept of the inauguration of the new President, according to the chief director of the ceremony V. Vovkun. This is the personality of the President himself and the study of European experience. The video materials with the inauguration of the presidents of the Czech Republic, Poland, Germany and others were revised, after which the main emphasis was placed on the study of Ukrainian history, dating back to the times of the princely, "Cossacks" and the Ukrainian People's Republic period. However, the determining factor was to be the people, for whom the ceremony was intended to mark an important event - the transition from the victory of the Orange Revolution to everyday work.

The official inauguration of the President of Ukraine V. Yushchenko took place on January 23, 2005 and consecutively consisted of such events as the ceremonial session of the Verkhovna Rada; a military ceremony at the Mariinsky Palace; the President's speech on Maidan Nezalezhnosti; an official reception of V. Yushchenko, organized for the heads of foreign delegations, a festive concert and fireworks.

In the Verkhovna Rada, according to the protocol, V. Yushchenko had to accept the power and its symbols from the hands of the previous President L. Kuchma. But after a tough battle for power on the Maidan, there was no question of any continuity. The new President was sworn in by the Chairman of the Constitutional Court of Ukraine N. Selivon. Putting his hand on the Constitution and on the Peresopnytsia Gospel, V. Yushchenko swore allegiance to the Ukrainian people. From the hands of the President of the Constitutional Court he received official symbols of power. In addition to the anthem in the Verkhovna Rada "Great God, the only One" was performed.

The President delivered the main speech to the people gathered on Maidan Nezalezhnosti, which the artists "dressed" in orange (the color of V. Yushchenko's election campaign), decorated with a poster with an exclamation mark and a horseshoe (symbols of his election campaign), placing garlands of orange checkboxes between the lamp posts.

According to the press service of President V. Yushchenko, about 500 thousand citizens have gathered in the central square of the Ukrainian capital. Guests were seated to the right and left of the presidential rostrum. The journalists who were on the Maidan noted the lively conversation between those who were located on the right hand side of President A. Kwasniewski and C. Powell. To his left were "the leaders of the revolution and those who actively sympathized with them (at least in their hearts - like Anatoly Chubais). Boris Nemtsov, a member of 
the political council of the Russian Union of Right Forces, stood with Yulia Timoshenko. They looked good" (Kolesnikov, 2005: 15).

The international significance of the processes taking place in Ukraine was emphasized by the presence of UN Deputy Secretary General Kofi Annan at the celebrations, although, as a rule, at such ceremonies in the UN member states he is represented by resident coordinators accredited in these countries.

In his speech V. Yushchenko called everything that happened during the elections "a victory of freedom over tyranny" and formulated the main idea - Ukraine's accession to the European Union. At the end T. Petrinenko's song "Ukraine" was sounded, and pigeons with orange ribbons on their legs and orange balloons flew into the sky. Members of the President's family were on the stage at that time, which, according to the authors of the ceremony, represented the state as a single Family. The concert in the Palace "Ukraine" ended with L. Beethoven's symphony No. 9 "Ode to joy", which was the basis for the European Union anthem.

The final chord of the action was a ball in the Ukrainian House, wrapped in an orange cloth (Tysachnaya, 2005: 26.01). The ball brought together the Ukrainian political, business, cultural elite, foreign guests - 1800 people. To decorate the interior in the form of a "miniMaidan" exhibits from the Museum of the "Orange Revolution" of the Kiev-Mohyla Academy were used. The second floor housed a photo exhibition and demonstrated video materials about the events of November - December 2004. Today, speaking about whether the so-called aura of power has been raised or lowered by the orange color, we have to admit that in this case the ceremonial contributed not to cohesion, but to intensify the split in society.

\section{Inauguration of Viktor Yanukovych and Peter Poroshenko}

The inauguration ceremony of the fourth president of Ukraine, Viktor Yanukovych, was held at a ceremonial meeting of the Ukrainian parliament. Representatives of the Ukrainian political elite and foreign guests gathered in the session hall of the Verkhovna Rada. Russia was represented by the Chairman of the State Duma Boris Gryzlov and the head of the presidential administration Sergei Naryshkin. The ceremony was attended by the ex-President of Ukraine Leonid Kuchma. Yulia Tymoshenko, ex-presidents L. Kravchuk and V. Yushchenko did not attend that meeting. In the parliamentary hall there were representatives of all factions of the Verkhovna Rada, except for the "Yulia Tymoshenko Bloc". Several presidents, prime ministers, speakers and more than a dozen heads of foreign delegations were present in the hall. Having read out the names of the honored guests the speaker V. Lytvyn invited V. Yanukovych to the hall.

The text of the oath of the Ukrainian President is enshrined in the Constitution of the country and consists of 58 words: "I, Viktor Yanukovych, elected President of Ukraine by the will of the people, assuming this high post, solemnly swear allegiance to Ukraine. I pledge with all my deeds to uphold the sovereignty and independence of Ukraine, to take care of the welfare of the Motherland and the well-being of the Ukrainian people, to defend the rights and freedoms of citizens, to comply with the Constitution of Ukraine and the laws of Ukraine, to fulfill my duties in the interests of all compatriots, to increase the authority of Ukraine in the world. After pronouncing it, the newly elected head of state signed the text of the oath. The standard of the President was brought into the hall. The head of the Constitutional Court of Ukraine A. Strizhak presented V. Yanukovych with a certificate of assumption of office and handed over the symbols of presidential power: a seal, a mace of the President of Ukraine and put on him a kolar (breastplate) - an order chain with coat of arms medallions. CEC Chairman V. Shapoval handed him the certificate of the President of Ukraine. 
V. Yanukovych began his speech with criticism of the "orange" team. "Poverty, a collapsed economy, corruption" - this is how he described the situation in the country and said that he knew how to fix the situation. After the meeting was declared closed, V. Yanukovych departed for the ceremony of transferring command of the Armed Forces of Ukraine, during which the flags of Ukraine and its President were raised. Following the sounded anthem and fireworks, the President entered the Secretariat hall as a master. (Chronicle, 2010: accessed 01.07.2014).

After the reception at the Ukrainian House, the President left for Donetsk for the UEFA match between Shakhtar Football Club and British Fulham Football Club. The visit to Donbass was seen as support for the owner of the Shakhtar Football Club team R. Akhmetov. Thus, the problems of the development of European football were opposed to the foreign policy interests of the state.

The first stage of oligarchic rule ended in tragedy for the people of Ukraine.

The election of the next President of Ukraine Peter Poroshenko was held on May 25, 2014 against the backdrop of a deep political crisis and a large-scale military operation in the East of the country. The Central Election Commission officially announced the self-nominated candidate P. Poroshenko the winner.

On June 7, the speaker of the Verkhovna Rada, Oleksandr Turchynov, opened a ceremonial meeting of parliament, at which the elected President took the oath of office to the Ukrainian people. The hall was attended by three previous heads of state - Leonid Kravchuk, Leonid Kuchma and Viktor Yushchenko, as well as P. Poroshenko's main rival in the finalized elections - former Prime Minister Yulia Tymoshenko.

At the beginning of the ceremony the President announced a minute of silence for those killed during the clashes in Ukraine. After P. Poroshenko took the oath and received the symbols of unity and power from the head of the Constitutional Court of Ukraine, he called on everyone who illegally took up arms to lay down them and promised amnesty to citizens who had not committed serious crimes. The President expressed his readiness to hold early elections in Donbass, while the issue of the territorial integrity of Ukraine is not subject to discussion, and also announced his intention to sign an association with the European Union (EU) as soon as possible, stressing that Ukraine was and will be a unitary state. As for relations with Russia, P. Poroshenko said: "Citizens of Ukraine will not be able to feel the benefits of peace and security until we settle our relations with the Russian Federation."

The predecessor of the newly elected President did not officially participate in the celebrations. It is also interesting to note that each new leader of the state declared that he would have to start everything practically from scratch. However, in general, the substantive part of the inaugurations in Ukraine really represents the government's program, which clearly defines the priorities in foreign and domestic policy.

\section{Inauguration of Vladimir Zelensky}

On Monday, May 20, 2019, in the building of the Verkhovna Rada in Kiev, the inauguration of President of Ukraine Vladimir Zelensky took place, for whom 73\% of Ukrainian voters voted. After the oath at the Peresopnytsia Gospel and the presentation of the symbols of the President of Ukraine, V. Zelensky made a speech.

At the beginning of his speech the President quoted his six-year-old son: "Dad, I watched on TV that Zelensky is the President. It turns out that I am the President as well". 
The President used a childish joke in the wording of the main idea of his speech: " $<\ldots>$ each of us is the President $<\ldots>$ This is not mine but our common victory" (Zelensky, 2019: accessed 09.07.2020).

Key phrases of the speech:

"Yes, we have chosen the path to Europe. But Europe is not somewhere out there, Europe will be here (in the head). And when Europe is here $<\ldots>$ it will be in Ukraine";

"Each of us is a migrant, those who have lost their home, and those who opened the doors of their own home, sharing this pain";

"I am ready to lose my popularity, my ratings, and if necessary, I am ready to lose my position without hesitation in order for peace to come";

"We must not talk about NATO standards, but create these standards";

"We are all Ukrainians wherever we live. Ukraine is not in the passport, Ukraine is in the heart" (Zelensky, 2019: accessed 09.07.2020).

At the end of his speech the President announced that he was dissolving the Verkhovna Rada of Ukraine.

In one of her monographs devoted to the history of state ceremonies of the Russian Empire, the author (Zakharova, 2003: 12-13) argues with the American researcher P. Wortman, who believes that state ceremonies are a scenario of power. But the scenario refers to the theater, and the state ceremony, in which the non-verbal language of communication really dominates, is not a scenario, but a real program of power, the main directions of which must be outlined in a speech and then confirmed by real legislative acts.

But V. Zelensky's speech, in our opinion, is precisely the scenario of the authorities. As you know, children cannot be overplayed. Quoting at the beginning of the speech the phrase of a 6-yearold kid, as well as advice to the citizens of Ukraine to place not portraits of the President in their offices, but photographs of their children, has a positive effect on consciousness more than the specifically proposed program, since these phrases are primarily addressed to the feelings of the voter.

It is important to note these truths are close to people not only in Ukraine but also abroad.

\section{Conclusions}

In our opinion, from the point of view of studying the inauguration of the President of Ukraine as a factor of cultural diplomacy, the inauguration of President V. Zelensky most closely meets the objectives of public diplomacy of the state, one of the components of which is cultural diplomacy.

The President's speech is not, to a large extent, a program of action, but a means by which other peoples and governments can change their attitude towards Ukraine, after which the conclusion of mutually beneficial agreements can follow.

But public diplomacy does not use false information for its own purposes and is not a medicine that can eliminate the problems of the state. Therefore, it makes no sense to talk about the prestige of the state without concrete actions by the authorities aimed at raising the standard of living of citizens, developing democratic institutions in society.

\section{References}

Hronika inauguratsionnyh torzhestv $v$ Ukraine [Chronicle of the inaugural celebrations in Ukraine]. URL: http://ib.ua/news/2010/02/25/28641-inauguratsiya-yanukovicha_kak_eto_b. html (accessed 01.07.2014). [in Russian] 
Kolesnikov A. Pervyiy Ukrainskiy [The First Ukrainian]. Kiev, 2005. p. 15. [in Russian] Lukin A.V. Publichnaya diplomatiya [Public diplomacy] // International life. 2013. № 3. p. 69-87. [in Russian]

Tyisyachnaya N. Beseda N. Tyisyachnoy s V. Vovkunom [Conversation of N. Tysachnaya with V. Vovkun]. // Day. 2005. January 26. [in Russian]

Zaharova O.Y. Vlast tseremonialov i tseremonialy vlasti v Rossiyskoy imperii XVIII - nachala $X X$ veka [Power of ceremonies and power ceremonies in the Russian Empire of the 18th-early 20th centuries]. M., 2003. p. 12-13. [in Russian]

Zelensky $V$. Tekst rechi $V$. Zelenskogo na inauguratsii [Text of V. Zelensky's speech at the inauguration]. URL: https://kh.vgorode.ua/news/sobytyia/397462-ynauhuratsyia-vladymyra-zelenskoho-hde-smotret-onlin (accessed 09.07.2020). [in Russian] 